\title{
Covid-19 and Sustainable Economic: How Badan Amil Zakat Nasional (Baznas) Sharing and Empowering Society
}

\author{
$1^{\text {st }}$ Boby Indrawan ${ }^{1}, 2^{\text {nd }}$ Ella Susanti ${ }^{2}, 3^{\text {rd }}$ Wiji Utami $^{3}, 4^{\text {th }}$ Deliza $^{4}, 5^{\text {th }}$ Tanti $^{5}, 6^{\text {th }}$ Rafiqoh \\ Ferawati $^{6}$ \\ \{bobyindrawan00@gmail.com ${ }^{1}$, ellasusanti@uinjambi.ac.id ${ }^{2}$,wijiutami@uinjambi.ac.id ${ }^{3}$, \\ deliza@uinjambi.ac.id ${ }^{4}$, tanti@uinjambi.ac.id ${ }^{5}$,rofiqohferawati@uinjambi.ac.id ${ }^{6}$ \}
}

UIN Sulthan Thaha Saifuddin Jambi ${ }^{1,2,3,4,5,6}$

\begin{abstract}
The world economy experienced a slump during the Covid-19 outbreak caused the shaking of the world economic system. The role of Baznas in sustainable economic improvement has been carried out using a descriptive qualitative approach. This study aims to determine the effectiveness of the zakat distribution and management system in Baznas during the pandemic. This research data collection method uses field research and literature studies. This study explains that Baznas has distributed zakat in 4 sectors, namely Small Medium Enterprise business, health, scholarships, and natural disasters. In addition, the zakat distribution management system at the Bungo Regency Baznas has been very well regulated in an integrated and digitalized, so that the recipient data and the amount of zakat can be seen in quantization. Theoretically, this research becomes a reference for Baznas management during the Covid-19 outbreak, while practically it is enormous to optimize the role of Baznas to improve a sustainable economy.
\end{abstract}

Keywords: Covid-19, Baznas, sustainable economic.

\section{Introduction}

A sustainable economy is a multi-functional economy that has an impact on various sectors of human life. However, during the Covid-19 pandemic, the economy experienced a slump which resulted in the world economic system being shaken. Affecting other sectors related to the economy such as Health, Education sector, and agriculture sector. However, according to the World Economic Situation and Prospects (WESP) report, after the global economy contracted by $3.6 \%$ in 2020 , it will increase by $5.4 \%$ in 2021 [1]. However, many people have felt the impact of the Covid-19 pandemic, including the lack of finance for access to health, school fees, and a decrease in the turnover of farmers [2]. This requires the government to carry out various integrity policies in helping Indonesia's economic recovery. Through the role of the government agency, the National Amil Zakat Agency (Baznas) helps sustainable economic recovery during the pandemic.

The role of Baznas as a distribution and empowerment institution is very helpful for the sustainable economy of the Indonesian people. As previous research related to the role of zakat in providing social protection in Jordan and Sudan stated that zakat was used for social protection by reaching family households, geographical conditions, and country politics [3]. Previous research has also examined zakat as an instrument of Islamic wealth by redistributing 
and alleviating poverty in Malaysia [4]. Zakat is not only social finance in helping the poor, but zakat can also be used as economic support for family and household businesses. Through the findings of previous research explains that zakat supports social security, micro takaful (Islamic microeconomics), and is sustainable [5]. So that the researchers conducted research that focused on the role of national Baznas in sharing and empowering a sustainable economy during the Covid-19 pandemic. Because during the pandemic, Indonesia's economy is very critical, so the role of social finance government institutions through Baznas is needed to maintain the economy and be sustainable. It is hoped that this research can be used as academic literature and to know the role of Baznas as a contribution to advancing a sustainable economy.

The distribution program of zakat funds in Indonesia is regulated in a systematic and integrated manner based on Law no. 23 of 2011. Through this legality, Baznas contributes to sustainable development in various sectors of Indonesian society [6]. Broadly speaking, the contribution of sustainable development carried out by Baznas in Indonesia can be explained based on previous research. Baznas's contribution also plays a role in SDGs 6 Clean water and sanitation, which facilitates rural communities to obtain clean water and toilets for the community [7]. The distribution of Baznas aid funds is regulated as well as possible as in previous research using the Bayesian AI network as a distribution medium for mustahiq zakat so that the data is right on target [8]. Therefore, this study focuses on the role of Baznas in a sustainable economy during the Covid-19 pandemic, it needs to be investigated to find out the real contribution of Baznas.

\section{Literatur Review}

\section{Zakat as Islamic social finance}

The religion of Islam pays close attention to the relationship with Allah and the relationship with humans to create inner and outer peace. In terms of relationship with Allah, see-through seriousness in carrying out orders and stay away from His prohibitions. In terms of relationships with humans, it can be seen from the social spirit and concern for fellow people. Therefore, to create good relations as a form of concern for fellow Muslims, zakat funds can be collected as a form of the social spirit of the Muslim community [9].

There are four components of Islamic finance, namely Islamic banking and its products, Islamic capital market, Islamic insurance, and Islamic wealth management. Through Islamic wealth management, it provides discussions on social and economic justice, alms, to the distribution of zakat. Islamic finance is not only limited to transactions for buying and selling but also aims to increase financial inclusion and poverty alleviation. Besides that, the meaning of financial inclusion in the discussion of zakat is that zakat can reach various segments of society as a provider of social financial services [10].

Zakat is the main source of economic, fiscal policy in Islam or can also be referred to as a tax for Muslims. Zakat is the main source of government revenue for the benefit of the Muslim community. The practice of zakat in Islamic social finance is seen from the achievement of the goals and benefits of zakat itself through mustahiq zakat or zakat recipients. Through zakat, the life of mustahiq zakat will be helped through zakat funds. But besides that, zakat is an obligation that must be paid by Muslims every year or known as zakat fitrah. In addition to zakat fitrah, there are several types of zakat, such as zakat on malls, zakat on gold and silver, zakat on trade, and zakat on livestock [11]. 


\section{The concept of zakat in the Qur'an}

Zakat is part of the obligations of Muslims that cannot be separated from life. Because zakat is one of the points of the third pillar of Islam. This explains that zakat is a fundamental instrument that is obligatory for every Muslim. As has been explained by Allah through His words through the Qur'an. The Qur'an strongly encourages its Muslims to issue zakat for the common good. Many foundational words explain zakat, one of which is the word of Allah in Q.S At Taubah 103 which means "Take zakat from some of their wealth, with zakat you clean and purify them and pray for them.". This verse tells us to pay zakat as a means of purifying wealth. It is also Q.S At Taubah 60 which explains that zakat is for the poor and needy, zakat collectors, converts, freed slaves, Muslims who have a lot of debt, people who travel in the way of Allah [12].

Zakat as a solution for Muslim cooperation in helping mustahiq zakat. However, zakat (fitrah) is also the obligation of Muslims to issue without exception. This is because the sustenance of every Muslim has a measure so that they are not complacent with the wealth of the world such as the qarun who drowns in wealth, as the word of Allah in QS Ash-Shura 27. Therefore, the concept of zakat has been explained in detail through the Quran about the importance of paying and distributing zakat and as a social action of cooperation in building the lives of Muslims [13].

\section{Management of zakat in Indonesia}

One of Islamic Philanthropy, zakat is determined and regulated through the Law of the Republic of Indonesia. The application and management of zakat are regulated in Law No. 23 of 2011 concerning zakat management. In Law 23 it is explained that zakat activities are carried out through planning, implementing, and coordinating the collection, distribution, and utilization of zakat funds. The reason is so that the benefits that are felt by the recipients of zakat can be distributed properly. The government pays close attention to how zakat is managed. Because zakat is a financial obligation that must be paid by the Muslim population [14].

The management of zakat in Indonesia is managed by the National Amil Zakat Agency or Baznas. This amil zakat institution operates at the district, provincial and national levels. The role of Baznas is to collect, distribute and utilize zakat which will be used for the benefit of mustahiq zakat and the general public. The management of zakat by the amil zakat institution must be managed with good and clean governance because the role of amil zakat is expected to be able to help the economy of the Indonesian Muslim community [15].

\section{Methodology}

This study uses a descriptive qualitative research method by managing data which is then described in the form of a description. Description analysis aims to explain social events, as well as phenomena in the community [16]. So this study focuses on the scope of the discussion on zakat funds managed by Baznas to be distributed in the community to support the sustainable economy of SDGs during the pandemic. Because during the pandemic, the community needs help from amil zakat as Islamic philanthropy. So to state the facts on the 
ground, this research uses primary data instruments directly obtained from Baznas. Researchers also use secondary data sourced from journals, websites, and reports to support primary data.

The analysis of qualitative data to be described is carried out through 4 stages starting from the stages of collecting, reducing, presenting, and ending with conclusions. Data collection was obtained through primary data and secondary data. Then the data redaction is done so that the data obtained is relevant to the research so that data that is not important is not used in this study. After the reduction, the data is presented so that the data used is structured according to research needs such as graphs and tables. With structured research data, conclusions can be drawn to find research results [17]. This study uses the Nvivo application as a tool to process and analyze the results of research interviews in the form of recordings. analysis processed by Nvivo forms a word cloud and image data.

\section{Result and Discussion}

\subsection{Introduction to Bungo Regency Baznas}

The Bungo Regency Baznas was previously part of the Regional Amil Zakat Agency (Bazda). Through the Decree of the Regent of Bungo Regency No. 437/Adm-Kesramasy of 2016 concerning the appointment of Bazda to become Baznas of Bungo Regency, so that it has reached the age of 5 years. Within 5 years of operation, fostering the people through the management of zakat funds and distribution to mustahiq zakat. The operational area of Baznas Bungo Regency consists of 17 sub-districts, 11 sub-districts, and 161 villages. The legality of a Baznas institution which is regulated by law and the scope of work based on each area has been determined by regulations from the central government and local government. [18]. That way the distribution and management of zakat activities are by government and religious guidelines. Based on interviews, when the status of Bazda was distributed, the distribution system was carried out by lending money to the community to open a business and it would be returned to Bazda. The application of such a system is because cash reserves are still small so that through loans, the financial benefits can rotate for other people who borrow. Meanwhile, while serving as Bazda, the distribution system was fully given to the community without any return in the future because Baznas' financial reserves increased. So that the distribution of zakat funds is fully to help the economy of the surrounding community [19].

The activities of Baznas Bungo Regency are carried out in several operational processes such as administration, zakat collection, distribution, and financial planning. Through this activity, the target has been achieved based on the 2020 Annual report. Administrative activities have achieved the agency's target well, have adequate inventory facilities and infrastructure, and professional implementing staff. Zakat collection activities reached the target of IDR 4,150,000,000 obtained through the Zakat Collection Unit (UPZ) and direct and online socialization. In line with previous research that explained the stages of collection through socialization to introduce the amil zakat institution to muzakki and mustahiq zakat [20]. Meanwhile, distribution activities are carried out as much as possible so that it is right on the target of mustahiq zakat to support a sustainable economy. In addition, financial planning activities have created good, safe, transparent, and accountable finances. Planning accountability is carried out manually, namely recording through books and then recapitulating using a computer. The financial planning of the Bungo Regency Baznas is the same as previous research using manual methods [21]. 
During the pandemic, the Bungo Regency Baznas continued to carry out zakat distribution and collection programs as appropriate. The role of Baznas through the distribution of funds is very important, especially during the pandemic. Because the pandemic affects the economic development of the community. During a pandemic, economic activities such as MSMEs running out of capital, termination of employment, and unemployment. Declining economic conditions can affect other sectors such as Health, Education, and other sectors [22]. Therefore, the role of Baznas during the pandemic has become public social finance as evidence of the concern of local governments through the zakat distribution program.

The Covid-19 pandemic has also informed Baznas management to implement the Health protocol. Based on the results of observations made by researchers, the results showed that the Health protocol applied was less than optimal. This is because there are still some administrators who lack the awareness to wear masks and health facilities such as first aid kits and hand sanitizer. The importance of implementing the Health protocol as Baznas' contribution in supporting efforts to limit the scale of the spread of the coronavirus outbreak in zakat institutions in administrative management [23].

\subsection{Distribution system effectiveness}

One of the objectives of this research is the effectiveness of the zakat fund distribution system. Through observation, interviews conducted with informants obtained the results: the distribution was carried out first in a field survey before distributing aid funds to both consumptive and productive actors. The distribution of consumptive aid is carried out for existing mustahiq to meet the needs of life such as living expenses, education costs, health costs, and disaster assistance. Meanwhile, productive distribution is carried out to the economic community to support a sustainable economy during the pandemic, such as business capital and livestock for the Anak Dalam Tribe. As in previous research, the effectiveness of zakat on Islamic economic growth stimulates the country's growth in various fields, from consumption, investment, government spending to community economic growth. [24].

Baznas is an institution that is authorized to carry out the task of managing, distributing, and supervising zakat funds in the Bungo district. Based on the results of interviews, the zakat distribution system in Baznas Bungo Regency makes a strategy for zakat management and development by introducing problems, creating business opportunities for mustahiq, developing productive businesses, and creating a network of small entrepreneurs. The effectiveness of the zakat fund distribution system carried out by the Bungo Regency Baznas during the Covid-19 pandemic is managed in an accountability manner. Through the financial reports produced by auditing as evidence of the accountability of the Baznas institution in being responsible for the management of zakat funds [25]. So it can be seen in table 1. based on the 2020 Bungo Regency Baznas annual report:

Table 1. Report on the distribution of zakat funds during the 2020 pandemic.

\begin{tabular}{llll}
\hline No & Type of activity & Mustahiq & distribution of funds \\
\hline 1 & Distribution of Travelers Aid & 11 people & Rp4.250.000 \\
2 & Distribution of Medical Aid & 28 people & Rp53.000.000 \\
3 & Distribution of Business Capital Assistance & 9 people & Rp45.500.000
\end{tabular}




\begin{tabular}{|c|c|c|c|}
\hline 4 & $\begin{array}{l}\text { Distribution of Underprivileged } \\
\text { Scholarships }\end{array}$ & 803 people & Rp388.000.000 \\
\hline 5 & Distribution of Aid for Muallaf & 48 people & Rp175.255.000 \\
\hline 6 & $\begin{array}{l}\text { Distribution of Sharia Economic Event } \\
\text { Assistance }\end{array}$ & - & Rp500.000 \\
\hline 7 & Fire Relief Distribution & 2 people & Rp15.000.000 \\
\hline 8 & Distribution of Al-Quran Aid & & Rp7.500.000 \\
\hline 9 & Distribution of Social Assistance & 3 people & Rp800.000 \\
\hline 10 & $\begin{array}{l}\text { Distribution of Consumptive, Honorary, and } \\
\text { Covid-19 Zakat }\end{array}$ & 15.475 people & Rp3.325.100.000 \\
\hline 11 & Distribution of Basic Food Aid & 229 people & Rp113.930.000 \\
\hline 12 & Distribution Load & & Rp1 19.845.800 \\
\hline 13 & $\begin{array}{l}\text { Distribution of Islamic Boarding Schools } \\
\text { and Mosques }\end{array}$ & & Rp20.000.000 \\
\hline 14 & Distribution of BPJS Arrears Aid & 4 people & Rp11.330.500 \\
\hline 15 & Distribution of Gharimin Aid & 1 people & Rp3.000.000 \\
\hline & Amount & 16.613 people & $\mathrm{Rp} 4.283 .011 .300$ \\
\hline
\end{tabular}

Based on interviews conducted on the effectiveness of the distribution of zakat funds, it turns out that Baznas Bungo Regency distributes funds on target. This can be seen in table 1 . The Covid-19 pandemic that hit did not limit Baznas to contribute to sustainable development, especially in the economic, health, education, and community sectors. This study also obtained a nominal distribution in sustainable development. Adequate distribution of nominal transfers provides managerial and administrative information on institutions regarding the funds disbursed [26].

The effectiveness of the zakat fund distribution system during the Covid-19 pandemic was carried out through 4 flagship programs of the Bungo Regency Baznas. Based on interviews with resource persons, they explained that these 4 flagship programs consist of Bungo Cares, Bungo Education, Bungo Healthy, and Bungo Religious. Each excellent program has implemented its distribution well. Distribution through the Bungo Cares program, such as providing necessities to nursing homes and fire assistance. Distribution through the Bungo Education program includes providing scholarships to students, be it educational scholarships, research scholarships, or scholarships for laptop facilities. Meanwhile, distribution through the Bungo healthy program, especially during the Covid-19 pandemic, is the distribution of $100 \mathrm{O} 2$ Tubes for Covid-19 patients in the Bungo Regency. Lastly, Bungo Religious is distributed through the construction of mosques and prayer rooms. The Bungo Regency Baznas contribution program during the pandemic is in line with previous research that carried out the healthy handwashing movement to avoid the spread of the coronavirus [27].

This study interviewed indicators of achievement of the implementation of the Baznas program in the Bungo Regency. The effectiveness of the distribution of zakat funds during the 
pandemic is carried out through 2 achievement indicators of program implementation, namely qualitative indicators, and quantitative indicators. Qualitative indicators are the increasing public trust in paying zakat in Baznas, the positive impact of distribution is felt by the community, the high interest of the community in submitting consumptive and productive proposals, and the amil zakat institution is getting stronger and independent. While the quantitative indicators are Cooperation with the government to increase the collection of zakat funds, collaboration with community leaders, customs, and MUI, the issuance of Bungo Regulation No. 18 of 2019 led to increased fundraising and professional workforce. In addition, policies that regulate Baznas institutions, both central and regional regulations, make the institution a government institution that is trusted to pay professional zakat. [28].

The contribution of the Bungo Regency Baznas to sustainable economic development during the pandemic can be done through the role of zakat distribution itself. Researchers are also directly involved in the field for the distribution of basic food assistance, fire assistance, business capital, educational scholarships, and the distribution of $\mathrm{O} 2$ tubes for Covid-19 patients in Bungo.

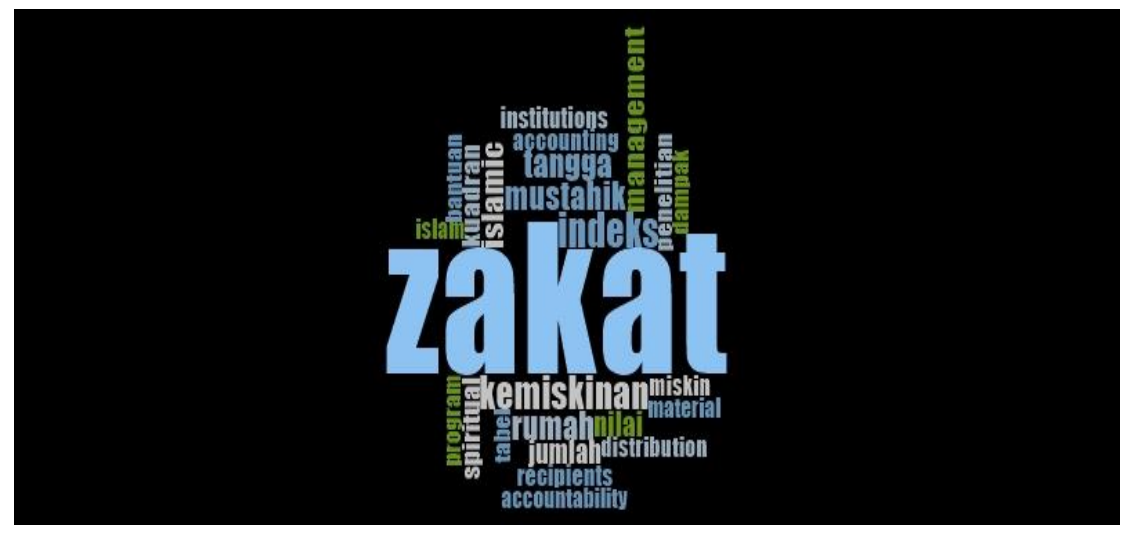

Fig. 1. Word Cloud.

Visualization of the results of the interview on the effectiveness of the zakat fund distribution system is carried out in Figure 1 through Wordcloud analysis. Three words often appear are Zakat, Index, and Poverty. The informant also stated that the effectiveness of the distribution was aimed at overcoming the poverty index in Bungo Regency. Moreover, the economic condition of the community during the pandemic is increasingly alarming. Based on a report from the Central Statistics Agency, the poverty index of the Bungo Regency community in 2020 was $422,801.00$ which increased from 2019 of 390,439.00 [29]. The Bungo Regency Poverty Index can also be seen from the number of people and the percentage of the poverty population in 2019 of 20,872 (5.60\%), an increase in 2020 of 22,070 (5.80\%) [30]. Baznas' positive response is by distributing aid funds to the poor in Bungo Regency. Bungo Regency Baznas seeks to reduce poverty levels during the pandemic with efforts to develop the people's economy through various programs for distributing aid funds. In line with previous research in determining zakat receipts through determining the size of poverty to meet the needs of life [31]. 


\subsection{Management of zakat in Baznas during a pandemic}

During the Covid-19 pandemic in 2020, the Bungo Regency Baznas continued to implement and manage work programs well. The work program has been structured in a structure. The short-term work program includes administrative management, socialization of Baznas, guidance for Human Resources, distribution of assistance based on Asnap (Mustahiq), and managing finances. The medium-term program includes quick and easy administrative services, creating a disciplined workforce, managing assistance for muzakki and mustahiq, as well as creating good and correct administration. While the long-term program is the creation of perfect administration, the creation of operational executives, the creation of awareness of the tithe of Muslims, and the creation of an independent and reliable Baznas. The more efficient the management of zakat funds, the more efficient the role played by Baznas in the distribution [32].

The current pandemic condition is increasing, so the participation and role of all components of the nation are very important so that the negative impact of the Covid-19 pandemic can be reduced and handled properly. The support and cooperation of various parties are needed so that all the resources owned by this nation can be utilized properly. One of the institutions that play a role in efforts to overcome the impact of Covid-19 is the zakat institution. The Bungo Regency Baznas has shown its involvement in response activities to this pandemic. By assisting underprivileged communities in terms of temporary basic needs, both in terms of the Baznas flagship program. As previous research stated that Baznas as a Sharia financial institution contributed to building the people's economy during the pandemic through various efforts, such as distributing funds directly to the public [33]. The effectiveness of zakat fund management during the pandemic is carried out through several steps. As shown in Figure 2. the management is carried out through the planning stage, collection stage, organizing stage, distribution stage, distribution stage, and evaluation stage. The management carried out aims to make the zakat fund management system through the contribution of Baznas beneficial. Because the agency's contribution provides profitability and savings that are useful for distribution [34]. 


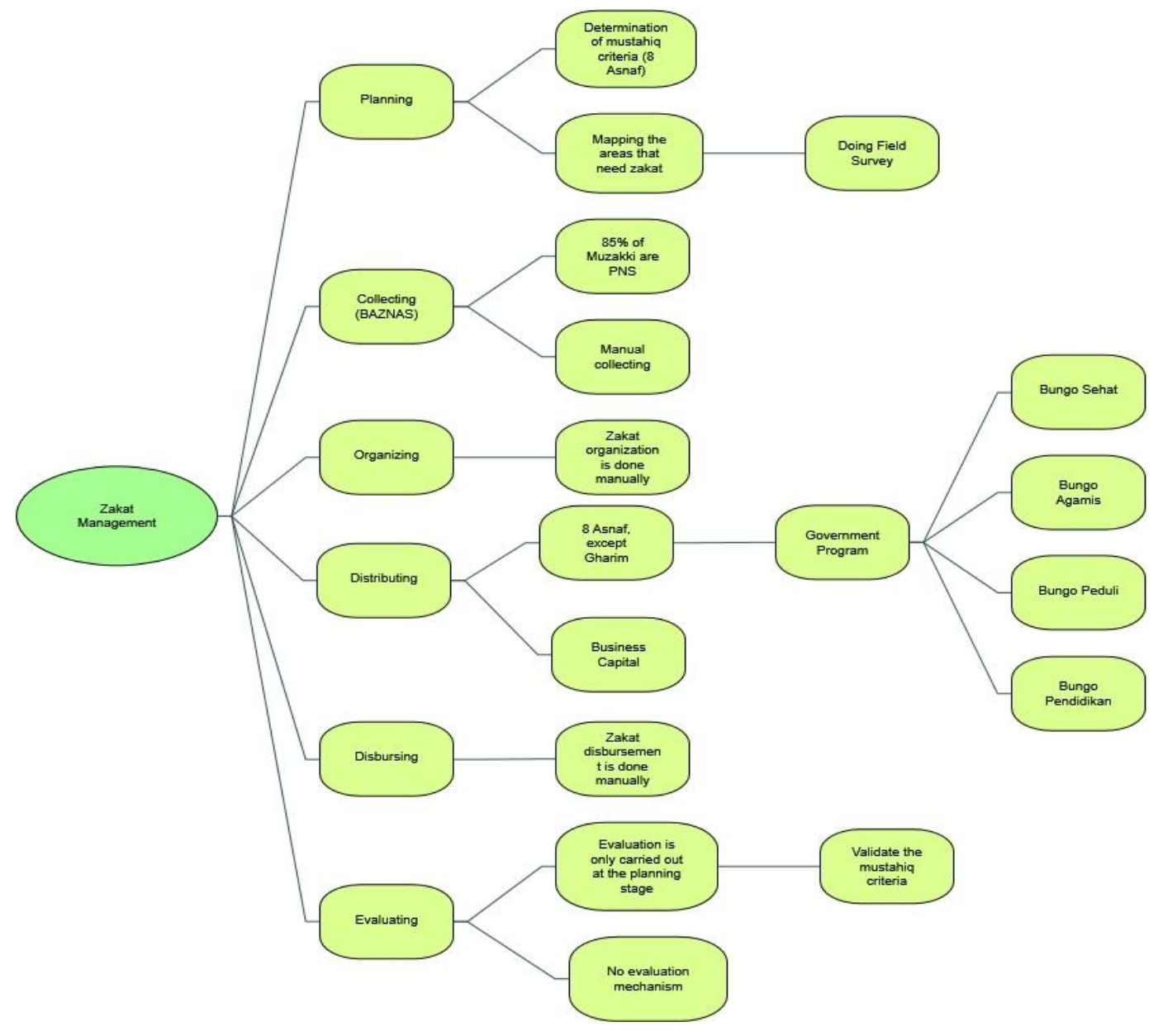

Fig. 2. zakat management.

The first stage of zakat fund management is carried out through planning. Planning is an early stage that requires seriousness and thoroughness to obtain maximum results [35]. Based on interviews, the planning stage is determined based on the criteria of 8 mushatif (ansaf) zakat and mapping of areas that need zakat. Criteria for 8 zakat mushatik consist of the Fakir, Poor, Riqab, Gharimin, Muallaf, Fiisabilillah, Ibn Sabil and Amil [36]. After being determined based on the 8 Mushatiq criteria, a mapping of the areas that need zakat funds is carried out. Regional mapping is the process of mapping an area in certain projections for better follow-up. Planning through regional mapping is carried out through direct field surveys by Baznas. Although the Covid-19 pandemic has not ended, field surveys are still being carried out by distributor staff. The field survey aims to ensure that the management of zakat funds is distributed on target to the community according to the 8 Mustahiq Zakat criteria.

The second stage in managing zakat funds during the Covid-19 pandemic is carried out by collecting zakat funds. Based on the results of the interview, it was stated that the stage of 
collecting zakat funds was carried out in 2 ways, namely manual collection and collection through the Zakat Collection Unit (UPZ). The manual collection is carried out through direct appeals and outreach, social media, and newspapers. The management of the collection stage has been described in previous research related to the socialization of zakat assistance programs carried out to improve skills and knowledge of amil zakat institutions and the obligation to pay zakat [37]. Meanwhile, the collection through the Zakat Collection Unit is carried out on civil servants in government and private institutions. Through the Bungo Regency Baznas annual report, agencies that contribute to being part of the Zakat Collection Unit are SKPD, Vertical Agency Offices, BUMD, BUMN, Private, Mosques, Schools, Districts, and urban villages. Through interviews also obtained the results of the largest collection of sources is on muzakki civil servants as much as $85 \%$ through the Zakat Collection Unit. While the rest is sourced manually from the people who pay zakat. This research is in line with previous research, the management of zakat fund collection is targeted at government and private institutions as well as the general public [38].

The third stage of managing zakat funds during the Covid-19 pandemic is carried out through organizing. Organizing aims to organize various activities according to a predetermined concept. As previous research stated that the management of zakat aid funds needs to be better organized so that the funds distributed are by the provisions of the agreed concept [39]. Organizing the management of zakat funds is done manually. Based on the results of the interview, it was stated that the organizing stage was carried out starting from the proposal, the condition of the area, the condition of the mustahiq candidate, research on the required funds, and approval of the receipt of aid funds. Organizers need to be applied in an institution in carrying out their duties and goals so that they are coordinated on target (source). Baznas Bungo serves every proposal that comes in and will organize its feasibility. As the findings of previous research on the service quality index of zakat institutions explain the importance of the service quality of amil zakat institutions to achieve the noble goal of socio-economic justice [40].

The fourth stage of managing zakat funds during the pandemic is carried out through distribution. The main purpose of distributing zakat funds is to build the people's economy. As in previous research, the distribution of zakat funds is aimed at financing community microenterprises [41]. Based on the results of the interview, it was stated that the distribution was carried out through 2 indicators, namely for 8 (Ansaf) mustahiq Zakat (except Ghorimin) and business capital. The distribution of 8 Ansaf is distributed through the Bungo Regency Baznas flagship program, namely Bungo Healthy, Bungo Religious, Bungo Cares, and Bungo Education. While the business capital indicator supports the Bungo community's sustainable economy during the Covid-19 pandemic. In addition, based on the 2020 annual report, the Bungo Regency Baznas flagship program is that the Bungo Sehat Program aims to show Baznas' contribution to Covid-19 patients through real work such as cash assistance and gas cylinder assistance. The Bungo Religious program fully supports religious activities such as Islamic economic seminars and Islamic holidays. The Bungo Cares program is a form of Baznas' concern for the economic condition of the Bungo community, such as providing basic materials to nursing homes and aid for firehouses. Meanwhile, the Bungo Education program aims to improve education through a program of educational scholarships and research scholarships. through the flagship program of Baznas Bungo, the distribution of zakat funds is used to alleviate poverty, meet the needs and support the economy of the people. As previous research stated that zakat is an act of purifying property and helping the economic condition of the community [42]. 
The fifth stage is the management of zakat funds during the pandemic through distribution. After the distribution, the funds are distributed to zakat mustahiq. In line with previous research, distribution management was continued with the distribution of aid funds to zakat mustahiq in alleviating poverty and building the economy of the people [43]. Based on the results of interviews, the results of the distribution of zakat funds are still done manually. Although financial technology is already present in social life, the distribution of zakat funds is still done manually. Manual distribution aims to ensure that the assistance is right on target, either in the form of money for business capital or in the form of business equipment.

The sixth stage of zakat fund management is carried out through evaluation. The evaluation aims to identify, measure and assess the performance of programs that have been implemented so that they can be improved in the next program. Baznas Bungo also evaluates each end of the management of zakat funds. However, based on interviews that the evaluation was only carried out at the planning stage, namely evaluating the validation of the mustahiq zakat criteria, there was no definite mechanism for evaluating. The evaluation stage is the management of the performance assessment of the management of zakat funds in integrity so as not to create gaps in the governance of the bureaucratic system to the contribution of the people's economic development [44].

\section{Conclusion}

The Covid-19 pandemic has had an impact on the Indonesian economy, such as poverty, layoffs, and unemployment. Through this research, we look at the role of government institutions, especially the Bungo Regency National Amil Zakat Agency in empowering the people's economy during the pandemic. So the purpose of this study is the effectiveness of the distribution and management system of zakat management by Baznas during the pandemic. The results of the study also show that the distribution of zakat funds is intended for zakat mustahiq, especially poor mustahiq. Various efforts were made, namely the provision of cash, business capital, and basic needs. Meanwhile, the management of zakat management by Baznas is regulated as well as possible through the stages of planning, collecting, organizing, distributing, distributing, and evaluating. So that the aid funds that are managed are right on target for people in need to build the people's economy during the Covid-19 pandemic.

\section{References}

[1] "World Economic Situation and Prospects as of mid-2021," 2021, pp. 173-204.

[2] K. D. Dzigbede and R. Pathak, "COVID-19 economic shocks and fiscal policy options for Ghana," J. Public Budgeting, Account. Financ. Manag., vol. 32, no. 5, 2020, doi: 10.1108/JPBAFM07-2020-0127.

[3] C. Bilo and A. C. Machado, "The role of Zakat in the provision of social protection: A comparison between Jordan and Sudan," Int. J. Sociol. Soc. Policy, vol. 40, no. 3-4, 2020, doi: 10.1108/IJSSP-11-2018-0218.

[4] S. H. A. Razak, "Zakat and waqf as instrument of Islamic wealth in poverty alleviation and redistribution: Case of Malaysia," Int. J. Sociol. Soc. Policy, vol. 40, no. 3-4, 2020, doi: 10.1108/IJSSP-11-2018-0208.

[5] S. A. Mikail, M. A. J. Ahmad, and S. S. Adekunle, "Utilisation of zakāh and waqf fund in microtakāful models in Malaysia: an exploratory study," ISRA Int. J. Islam. Financ., vol. 9, no. 1, 2017, doi: 10.1108/JJIF-07-2017-010.

[6] R. S. Rahmat and M. S. Nurzaman, "Assesment of zakat distribution: A case study on zakat 
community development in Bringinsari village, Sukorejo district, Kendal," Int. J. Islam. Middle East. Financ. Manag., vol. 12, no. 5, 2019, doi: 10.1108/IMEFM-12-2018-0412.

[7] F. A. Hudaefi, A. A. Y. Saoqi, H. Farchatunnisa, and U. L. Junari, "ZAKAT AND SDG 6: A CASE STUDY OF BAZNAS, INDONESIA,” J. Islam. Monet. Econ. Financ., vol. 6, no. 4, 2020, doi: 10.21098/jimf.v6i4.1144.

[8] Akbarizan, R. Kurniawan, M. Z. A. Nazri, S. N. H. S. Abdullah, S. Murhayati, and Nurcahaya, "Using Bayesian network for determining the recipient of Zakat in BAZNAS Pekanbaru," 2018, doi: 10.1109/ICon-EEI.2018.8784142.

[9] A. U. Farouk, K. Md Idris, and R. A. J. Bin Saad, "Moderating role of religiosity on Zakat compliance behavior in Nigeria," Int. J. Islam. Middle East. Financ. Manag., vol. 11, no. 3, 2018, doi: 10.1108/IMEFM-05-2017-0122.

[10] N. A. Zauro, R. A. J. Saad, and N. Sawandi, "Enhancing socio-economic justice and financial inclusion in Nigeria: The role of zakat, Sadaqah and Qardhul Hassan," J. Islam. Account. Bus. Res., vol. 11, no. 3, 2020, doi: 10.1108/JIABR-11-2016-0134.

[11] R. A. J. Saad and A. U. Farouk, "A comprehensive review of barriers to a functional Zakat system in Nigeria: What needs to be done?," International Journal of Ethics and Systems, vol. 35, no. 1. 2019, doi: 10.1108/IJOES-06-2018-0090.

[12] M. Y. Owoyemi, "Zakat management: The crisis of confidence in zakat agencies and the legality of giving zakat directly to the poor," J. Islam. Account. Bus. Res., vol. 11, no. 2, 2020, doi: 10.1108/JIABR-07-2017-0097.

[13] H. S. Nahar, "Exploring stakeholders' views on a corporatized zakat institution's management performance," Int. J. Ethics Syst., vol. 34, no. 4, 2018, doi: 10.1108/IJOES-08-2018-0115.

[14] Puskas BAZNAS, Outlook Zakat Indonesia 2020, vol. 66. 2020.

[15] BAZNAS, “Outlook Zakat Indonesia 2018," 2018.

[16] S. L. Gill, "Qualitative Sampling Methods," J. Hum. Lact., vol. 36, no. 4, doi: $10.1177 / 0890334420949218$.

[17] A. B. Hamilton and E. P. Finley, "Reprint of: Qualitative methods in implementation research: An introduction," Psychiatry Res., vol. 283, 2020, doi: 10.1016/j.psychres.2019.112629.

[18] I. Yahya, "Zakat Management in Indonesia: a Legal Political Perspective," Al-Ahkam, vol. 30, no. 2, pp. 195-214, Oct. 2020, doi: 10.21580/ahkam.2020.30.2.6420.

[19] A. Roziq, C. Wijayanti, and R. Irmadariyani, "Modification of TAM model application of system of information of management of BAZNAS in Indonesia," Int. J. Sci. Technol. Res., vol. 9, no. 4, pp. 1889-1893, Apr. 2020.

[20] F. Farkhah, "Analysis of strategies zakat, infaq, and alms collection at BAZNAS Semarang Regency," Indones. J. Islam. Econ. Res., vol. 2, no. 1, pp. 35-45, Aug. 2020, doi: 10.18326/ijier.v2i1.4214.

[21] N. F. Latief, D. P. E. Saerang, H. Karamoy, and S. Murni, "The accountability of zakat management in baznas of north Sulawesi province," Ann. Rom. Soc. Cell Biol., vol. 25, no. 2, 2021.

[22] R. M. T. A. D. Wicaksono and R. P. Rinaldi, "ECONOMIC DETERMINANTS OF GROWTH ACCELERATION DURING COVID-19 PANDEMIC: A COMPARATIVE STUDY BETWEEN INDONESIA, THAILAND AND VIETNAM," J. Dev. Econ., vol. 6, no. 1, 2021, doi: 10.20473/jde.v6i1.20834.

[23] F. A. Hudaefi, R. E. Caraka, and H. Wahid, "Zakat administration in times of COVID-19 pandemic in Indonesia: a knowledge discovery via text mining," Int. J. Islam. Middle East. Financ. Manag., 2021, doi: 10.1108/IMEFM-05-2020-0250.

[24] K. Ben Jedidia and K. Guerbouj, "Effects of zakat on the economic growth in selected Islamic countries: empirical evidence," Int. J. Dev. Issues, vol. 20, no. 1, 2021, doi: 10.1108/IJDI-05-20200100 .

[25] D. Megawati, "Implementation of Auditing in Zakat Institutions: Case studies of BAZNAS Riau and Pekanbaru," Tazkia Islam. Financ. Bus. Rev., vol. 12, no. 2, Sep. 2018, doi: 10.30993/tifbr.v12i2.133.

[26] M. Ahmad, "An empirical study of the challenges facing zakat and waqf institutions in Northern Nigeria," ISRA Int. J. Islam. Financ., vol. 11, no. 2, 2019, doi: 10.1108/IJIF-04-2018-0044. 
[27] A. Asfar, S. Sudarman, and H. Amir, "The Effect Of Hand Wash Training On Hand Higyene Behavior In Elementary School Students at SDAI Baznas South Sulawesi," Str. J. Ilm. Kesehat., vol. 9, no. 2, pp. 528-534, Nov. 2020, doi: 10.30994/sjik.v9i2.333.

[28] S. Kusriyah, "Government policy in achieving community welfare through the effectiveness of management of Zakat in Indonesia," Journal of Critical Reviews, vol. 7, no. 5. Innovare Academics Sciences Pvt. Ltd, pp. 157-165, 2020, doi: 10.31838/jcr.07.05.26.

[29] BPS, "Garis Kemiskinan Menurut Kabupaten/Kota (Rupiah/kapita/bulan), 2019-2020,” Badan Pusat Statistik, 2021. .

[30] BPS Kabupaten Bungo, "Kabupaten Bungo Dalam Angka 2020,” 2020.

[31] B. O. Ahmed, F. Johari, and K. A. Wahab, "Identifying the poor and the needy among the beneficiaries of zakat Need for a zakat-based poverty threshold in Nigeria," Int. J. Soc. Econ., vol. 44, no. 4, 2017, doi: 10.1108/IJSE-09-2015-0234.

[32] K. B. Mohd Khambali @ Hambali, Z. L. Hamzah, M. Z. Daud, and F. Johari, "Managing the Institution of Zakat: Case Study of Muallaf in Selangor, Malaysia," in Advances in Islamic Finance, Marketing, and Management, 2016.

[33] A. Fitriani, "The Effectiveness of Cash For Work in Handling the Impact of COVID-19," Int. Conf. Zakat, pp. 127-138, Oct. 2020, doi: 10.37706/iconz.2020.235.

[34] S. Javaid and H. A. N. Al-Malkawi, "Corporate social responsibility and financial performance in Saudi Arabia: Evidence from Zakat contribution," Manag. Financ., vol. 44, no. 6, 2018, doi: 10.1108/MF-12-2016-0366.

[35] S. Aripin, K. A. Rashid, A. A. Sarkawi, S. F. Hasan, and P. N. F. N. M. Fauzi, "Zakat houses design and planning (Quality and standard) from shariah perspective," Plan. Malaysia, vol. 17, no. 1, 2019, doi: 10.21837/pmjournal.v17.i9.596.

[36] Y. Ismail, A. B. Awang, and S. bin M. Sarif, "Re-Categorizing Recipients of Zakat Under Riqab For Sustainable Development Goals," Int. J. Zakat Islam. Philanthr., vol. 2, no. 1, 2020.

[37] A. Hasan, R. Hassan, E. R. A. Engku Ali, E. M. T. Engku Ali, M. Abduh, and N. H. Noordin, "A proposed human resource management model for zakat institutions in Malaysia," ISRA Int. J. Islam. Financ., vol. 11, no. 1, 2019, doi: 10.1108/IJIF-10-2017-0036.

[38] M. Kashif, K. Faisal Jamal, and M. Abdur Rehman, "The dynamics of Zakat donation experience among Muslims: a phenomenological inquiry," J. Islam. Account. Bus. Res., vol. 9, no. 1, 2018, doi: 10.1108/JIABR-01-2016-0006.

[39] D. R. Indika, S. N. F. Himawan, and E. A. Firmansyah, "IMPACT OF INCOME, CONSUMPTION, SAVING, AND NUMBER OF ZAKAT MANAGEMENT ORGANIZATIONS ON THE ZAKAT FUND COLLECTION," J. Bisnis dan Manaj., vol. 21, no. 2, 2020, doi: 10.24198/jbm.v21i2.499.

[40] N. Abd. Wahab, Z. Zainol, and M. Abu Bakar, "Towards developing service quality index for zakat institutions," J. Islam. Account. Bus. Res., vol. 8, no. 3, 2017, doi: 10.1108/JIABR-09-20150040 .

[41] N. I. Muhd Adnan et al., "Zakat distribution through micro financing: Hukm (islamic ruling) and form of aqad (contract)," J. Crit. Rev., vol. 7, no. 5, pp. 1032-1038, 2020, doi: 10.31838/jcr.07.05.208.

[42] M. H. Riyaldi, S. Suriani, and R. Nurdin, "Optimization Zakat for Sustainable Development Goals: Evidence from Baitul Mal Aceh,” Int. Conf. Zakat, 2020, doi: 10.37706/iconz.2020.223.

[43] N. Ardiani, "THE EFFICIENCY OF ZAKAT COLLECTION AND DISTRIBUTION: EVIDENCE FROM DATA ENVELOPMENT ANALYSIS," al-Uqud J. Islam. Econ., vol. 3, no. 1, 2019, doi: 10.26740/al-uqud.v3n1.p54-69.

[44] S. A. Basir, I. Abdul Ghani Azmi, S. H. Syed Ismail, P. Ibrahim, and H. A. Mohamed, "Malaysian Islamic quality management system MS1900: An implementation steps at Malacca Zakat Center," Humanomics, vol. 33, no. 2, 2017, doi: 10.1108/H-10-2016-0078. 